\title{
Article
}

\section{Lead Contamination of Potable Water Due to Nitrification}

Yan Zhang, Allian Griffin, Mohammad Rahman, Ann Camper, Helene Baribeau, and Marc Edwards

Environ. Sci. Technol., Article ASAP • DOI: 10.1021/es802482s • Publication Date (Web): 10 February 2009

Downloaded from http://pubs.acs.org on February 12, 2009

\section{More About This Article}

Additional resources and features associated with this article are available within the HTML version:

- Supporting Information

- Access to high resolution figures

- $\quad$ Links to articles and content related to this article

- Copyright permission to reproduce figures and/or text from this article

\section{View the Full Text HTML}


Lead Contamination of Potable Water Due to Nitrification

\begin{abstract}
YAN ZHANG, ${ }^{\dagger}$, , ALLIAN GRIFFIN, ${ }^{\dagger}$ MOHAMMAD RAHMAN, ${ }^{\ddagger}$ ANN CAMPER, HELENE BARIBEAU, ${ }^{\circledR}$ AND MARC EDWARDS*,†

Civil and Environmental Engineering Department, Virginia Tech, 418 Durham Hall, Blacksburg, Virginia 24061, Civil Engineering Department, Montana State University, 205 Cobleigh Hall, Bozeman, Montana 59717, and Carollo Engineers, 199 South Los Robles Avenue, Suite 530, Pasadena, California 91101
\end{abstract}

Received September 3, 2008. Revised manuscript received December 30, 2008. Accepted January 2, 2009.

Nitrification can increase levels of soluble lead in potable water by reducing $\mathrm{pH}$. The magnitude of the $\mathrm{pH}$ drop depends on the initial alkalinity and extent of nitrification. At $100 \mathrm{mg} / \mathrm{L}$ alkalinity as $\mathrm{CaCO}_{3}$, complete nitrification did not significantly decrease $\mathrm{pH}$ ( $\mathrm{pH}$ stayed $>7.5$ ) or increase lead contamination of water for lead pipe, but at $15 \mathrm{mg} / \mathrm{L}$ alkalinity, nitrification decreased the $\mathrm{pH}$ by 1.5 units ( $\mathrm{pH}$ reduced to $<6.5$ ) and increased soluble lead contamination by 65 times. Lower $\mathrm{pH}$ values from nitrification also leached $45 \%$ more lead and $81 \%$ more zinc from leaded brass connected to PVC pipes relative to the same situation for copper pipes. Particulate lead leaching was high but did not vary dependent on nitrification. While nitrification also produces nitrite and nitrate and reduces inorganic carbon and dissolved oxygen, these factors did not significantly impact lead leaching in this work.

\section{Introduction}

As United States utilities switch to chloramines for residual disinfection of potable water $(1,2)$ there is concern about potential costs and health implications of corrosion induced by nitrification (1). Nitrification, conversion of ammonia to nitrite $\left(\mathrm{NO}_{2}^{-}\right)$and then nitrate $\left(\mathrm{NO}_{3}{ }^{-}\right)$by nitrifying bacteria, could impact corrosion by decreasing $\mathrm{pH}$, alkalinity, and dissolved oxygen (1). Production of organic carbon and accelerated disinfectant decay might also stimulate growth of corrosion-influencing microbes (1,3). A 1991 survey indicated that two-thirds of the medium and large utilities that use chloramines report nitrification problems in water mains (3), and it is very likely that even a greater percentage would have nitrification issues if premise plumbing is considered $(1,4)$.

There is some limited anecdotal evidence of corrosion problems triggered by chloramines and nitrification in at least some circumstances. For example, recent work in Pinellas County, FL, highlighted some concerns related to iron corrosion control and red water (5). Likewise, elevated

* Corresponding author phone: (540)231-7236; fax: (540)231-7916; e-mail: edwardsm@vt.edu.

${ }^{\dagger}$ Virginia Tech.

\# Current address: DXV Water Technologies, Inc., 1451 Edilger Ave., unit B, Tustin, California 92780.

₹ Montana State University.

${ }^{\S}$ Carollo Engineers. copper levels at the tap were suspected to be linked to action of nitrifying bacteria in Willmar, MN, homes (6). Nitrification also co-occurred with higher lead leaching in Ottawa (7), Washington DC, and Durham and Greenville, NC, homes $(8-10)$. However, any link between nitrification and increased lead contamination was not definitive, nor were mechanisms postulated except for the case of Ottawa for which it was proposed that the higher lead resulted from decreased $\mathrm{pH}$ due to nitrification (7).

Given the high costs and health implications of corrosion to utilities and consumers $(8,10)$ and further considering that prior research emphasized nitrification problems occurring in the main distribution system whereas virtually all lead and copper plumbing materials are located within premise plumbing (11), it is important to better understand effects of nitrification on corrosion and metal release. The objective of this study was to scientifically verify anecdotal links established between nitrification and increased lead leaching through a well-controlled laboratory study, solubility modeling, and field work at water utilities.

\section{Experimental Section}

Water Chemistry. Lead pipes $(1.9 \mathrm{~cm} \times 30 \mathrm{~cm})$ were aged by exposure to a synthesized water for 1 year without nitrification and then exposed to water with $2 \mathrm{mg} / \mathrm{L}-\mathrm{N}$ ammonia (and resulting nitrification) for 15 months as described elsewhere (4). No disinfectant had ever been added to the pipes. Thirty pipes were exposed at 5, 60, and 1000 ppb orthophosphate-P (10 at each phosphate level), representing low, moderate, and high levels of phosphate typically encountered in potable water distribution systems. The 10 replicate pipes were separated into three groups. The first group continued as a control (4 pipes), and the second group was modified by addition of free chlorine to a final concentration of $10 \mathrm{mg} / \mathrm{L}$ total chlorine (3 pipes). The added chlorine reacted with the ammonia to form almost exclusively monochloramine (residual free chlorine and free ammonia undetectable). The third group of pipes was modified by addition of $1 \mathrm{mg} / \mathrm{L}$ chlorite (3 pipes). The high chloramine (12) and chlorite $(13,14)$ levels were added to inhibit nitrification, which was allowed to proceed unimpeded in the control. The $\mathrm{pH}$ of each type of water was adjusted to 8 before filling up the pipe. The alkalinity of the water was dropped stepwise from $100 \mathrm{mg} / \mathrm{L}$ to 30,15 , and then $0 \mathrm{mg} / \mathrm{L}$ alkalinity by decreasing the amount of $\mathrm{NaHCO}_{3}$ added. Each alkalinity level was maintained for sufficient time for nitrification, final $\mathrm{pH}$, and lead leaching to stabilize. Water in the pipes was changed twice a week, and pipes were maintained at room temperature.

Analytical Methods. Nitrifier activity was measured by loss of ammonia, production of nitrite and nitrate, and reduction of $\mathrm{pH}$. $\mathrm{pH}$ was monitored using a $\mathrm{pH}$ electrode according to Standard Method $4500-\mathrm{H}^{+} \mathrm{B}$ (15). Total ammonia $\left(=\mathrm{NH}_{3}+\mathrm{NH}_{4}{ }^{+}\right)$was measured using a salicylate method with a HACH DR/2400 spectrophotometer according to Standard Method $4500-\mathrm{NH}_{3}$ (15). $\mathrm{NO}_{2}{ }^{-} \mathrm{N}$ and $\mathrm{NO}_{3}{ }^{-} \mathrm{N}$ were measured using DIONEX, DX-120 ion chromatography, according to Standard Method 4110 (15). Dissolved lead was operationally defined as that which passed through a 0.45 $\mu \mathrm{m}$ pore size syringe filter. Total metal release was quantified by digesting samples with $2 \%$ nitric acid for $24 \mathrm{~h}$ in a $90{ }^{\circ} \mathrm{C}$ oven. Metal concentrations were quantified using an inductively coupled plasma mass spectrophotometer (ICP-MS) according to Standard Method 3125-B (15).

Case Studies. Two types of case studies were conducted. Water Utility Studies. Five participating utilities coordi- 


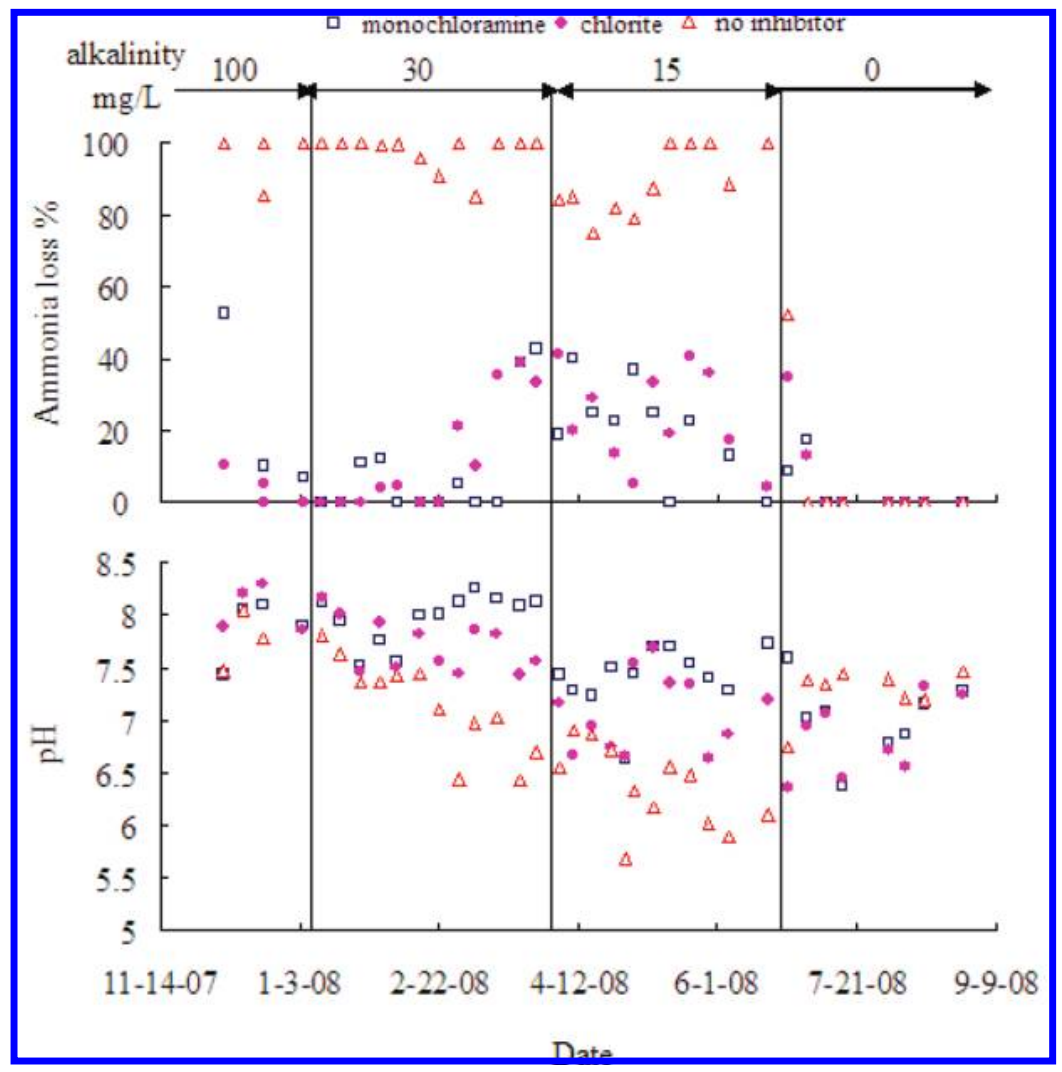

FIGURE 1. Ammonia loss $\%$ and final $\mathrm{pH}$ versus time when initial alkalinity was reduced in stages from 100 to $0 \mathrm{mg} / \mathrm{L}$. All pipes were dosed with $1 \mathrm{mg} / \mathrm{L}$ as $P$.

nated the collection of samples at three consumer homes before and after stagnation. Samples were analyzed for ammonia, nitrite, nitrate, lead, and copper release and other basic water quality parameters $(\mathrm{pH}$, chlorine, alkalinity, temperature, HPC, etc). More details of the sampling procedures are included in the Supporting Information.

Montana Bench Test. A plumbing rig was constructed to directly test the effect of pipe material (PVC versus copper) on nitrification and resulting lead contamination of water by leaded brass. A brass rod $(0.64 \mathrm{~cm}$ diameter $\times 10 \mathrm{~cm}$ length, C35300 alloy with $2 \%$ lead) was machined and placed inside a PVC or copper pipe ( $1.3 \mathrm{~cm}$ diameter $\times 61 \mathrm{~cm}$ length) to simulate the situation in homes with $\mathrm{PVC} /$ copper plumbing and leaded brass faucets. The brass rod was not in electrical contact with the PVC or copper pipe. Each experiment was run in triplicate using synthesized potable water containing nitrifying bacteria. The synthesized water contained $\left(\mathrm{NH}_{4}\right)_{2} \mathrm{SO}_{4}(2.13 \mathrm{mg} / \mathrm{L}-\mathrm{N})$, initial $\mathrm{pH}$ of $8.15, \mathrm{Na}_{2} \mathrm{HPO}_{4}(1 \mathrm{mg} /$ $\mathrm{L}-\mathrm{P}), \mathrm{NaHCO}_{3}\left(35 \mathrm{mg} / \mathrm{L}\right.$ as $\mathrm{CaCO}_{3}$ ), Elliot Humics (4 mg/L as C), and other salts described elsewhere (16). Water in the pipes was changed every Monday, Wednesday, and Friday, and samples were analyzed for ammonia, $\mathrm{pH}$, lead, and zinc release as described above.

\section{Results and Discussions}

Inhibition of Nitrification with Monochloramine/Chlorite vs Control Condition. Addition of either chloramine or chlorite effectively inhibited nitrification in the lead pipes relative to the situation without a nitrification inhibitor. Ammonia conversion to nitrate and nitrite (i.e., ammonia loss) decreased from $>80 \%$ in the control without inhibitor to $<40 \%$ upon addition of chloramine or chlorite (Figure 1).

On the basis of nitrification stoichiometry, $14 \mathrm{mg} / \mathrm{L}$ as $\mathrm{CaCO}_{3}$ alkalinity is consumed for every milligram of $\mathrm{NH}_{4}{ }^{+}-\mathrm{N}$ oxidized (17), and it was expected that nitrification could be somewhat limited by a lack of alkalinity (usually carbonate species) at approximately $6 \%$ of U.S. utilities with water containing $\leq 15 \mathrm{mg} / \mathrm{L}$ alkalinity as $\mathrm{CaCO}_{3}$ (18). However, in this study, for the control pipes, virtually complete nitrification occurred even when the added carbonate alkalinity was $15 \mathrm{mg} / \mathrm{L}$ (Figure 1). But at least some inorganic carbon is required for autotrophic nitrification, and when no carbonate was added, nitrification was abruptly halted even in the control (Figure 1). On the basis of this result, it is unlikely that nitrification will be inorganic carbon limited at water utilities unless alkalinity is well below $15 \mathrm{mg} / \mathrm{L}$ as $\mathrm{CaCO}_{3}$.

All other factors being equal, a lesser amount of nitrification translated to a higher final $\mathrm{pH}$ in the pipe because less acid is produced via nitrification (1). However, due to the relatively high buffering capacity of the water at $100 \mathrm{mg} / \mathrm{L}$ alkalinity, $\mathrm{pH}$ values in the pipes with monochloramine/ chlorite were only slightly higher $(p \geq 0.04)$ relative to the control condition (Figure 1). But, when alkalinity (and buffering) was decreased to $30 \mathrm{mg} / \mathrm{L}$ and then $15 \mathrm{mg} / \mathrm{L}$, the final $\mathrm{pH}$ values with monochloramine/chlorite were much higher $(p<0.001)$ than in the control (Figure 1). Thus, the extent of $\mathrm{pH}$ reduction by nitrification depends not only on the extent of nitrification but also on the initial alkalinity levels. At 0 alkalinity, where nitrification stopped in the controls, $\mathrm{pH}$ values in the pipes with monochloramine/ chlorite were actually slightly lower relative to that without inhibitors ( $p \geq 0.005$ ) (Figure 1).

The above results were examined relative to predicted trends using solubility and chemical reaction models. Predictions of final pH based only on bulk water chemistry and the expected acid production by nitrification confirms that the extent of the $\mathrm{pH}$ drop should increase with decreasing alkalinity (Supporting Information, Figure S-1). In fact, the predicted $\mathrm{pH}$ drops correlate very well with actual measured $\mathrm{pH}$ drops $\left(R^{2}=0.81-1\right)$, although the actual $\mathrm{pH}$ drop is 


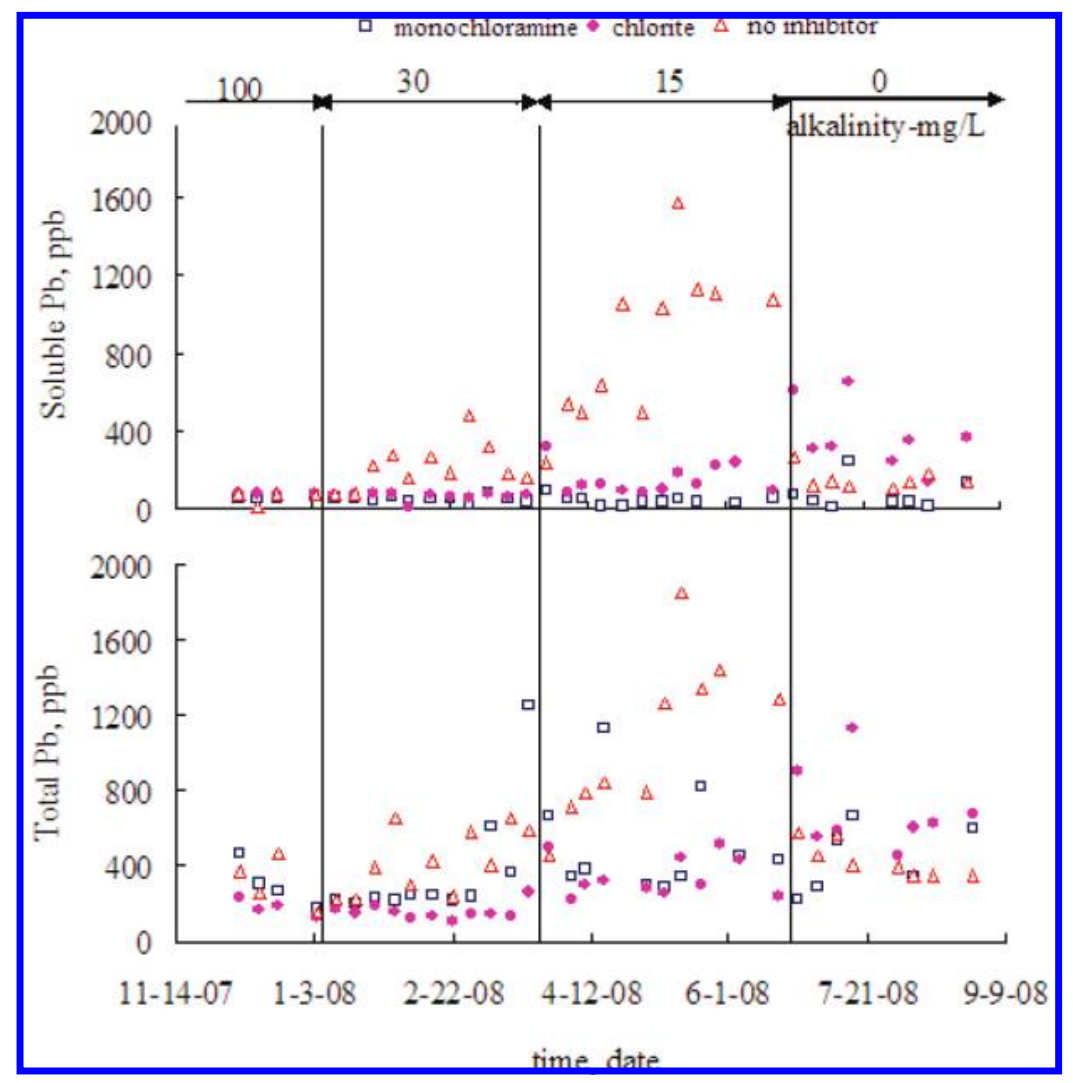

FIGURE 2. Total and soluble lead release versus time in lead pipes at $1 \mathrm{mg} / \mathrm{L}$ as $P$.

typically only $60-90 \%$ of the predicted $\mathrm{pH}$ drop. It is not uncommon to see differences between the predicted and actual $\mathrm{pH}$ drops due to other reactions (i.e., scale dissolution and corrosion) that tend to increase the $\mathrm{pH}$ (19).

Effect of Nitrification on Lead Release. Reductions in $\mathrm{pH}$ due to nitrification have been hypothesized to increase lead release $(1,20,21)$, although there has been no research that directly confirmed this hypothesis (19). In this study, a head to head comparison of pipes with nitrification inhibitors to those without confirmed that nitrification increased lead release, but the extent of the effect is highly dependent on the initial alkalinity level (Figure 2). Specifically, at $100 \mathrm{mg} / \mathrm{L}$ alkalinity lead release was not increased by nitrification, as indicated by similar or even higher total and soluble lead release in the pipes with monochloramine/chlorite versus the condition without nitrification inhibitor (Supporting Information, Table S-1, Figure 2). At $30 \mathrm{mg} / \mathrm{L}$ alkalinity, nitrification increased total lead release up to 5 times and soluble lead release up to 21 times ( $p \leq 0.002$, Table S- 1 ) (Figure 2). At $15 \mathrm{mg} / \mathrm{L}$ alkalinity, total lead release was increased up to 5.5 times and soluble lead release up to 65 times ( $p \leq 0.00008$, Table S-1, Supporting Information) (Figure 2). These trends are in agreement with expectations given that the $\mathrm{pH}$ was reduced most significantly by nitrification at the lower alkalinity levels (Figure 1). When alkalinity dropped to 0 , lead release for the control pipes dropped to levels similar (or even slightly lower) to those observed with monochloramine/chlorite (Figure 2, Table S-1, Supporting Information), proving that the nitrification inhibitors themselves were not abiotically decreasing solublity or total lead.

It was also considered possible that soluble microbial products (SMP) produced by nitrification might be increasing lead solubility. However, based on data from earlier studies (22), nitrification of $2 \mathrm{mg} / \mathrm{L}$ ammonia would produce 20 ppb-C SMP from autotrophic growth, which is not sufficient

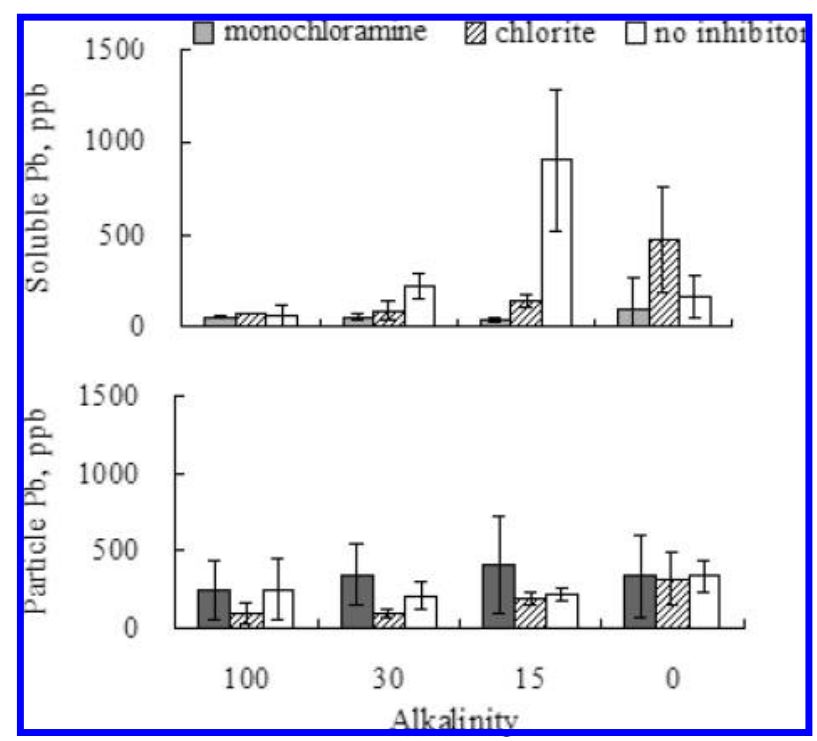

FIGURE 3. Average soluble and particulate lead release at different alkalinity levels and $1 \mathrm{mg} / \mathrm{L}$ as $\mathrm{PO}_{4}-\mathrm{P}$. Error bars indicate $95 \%$ confidence interval.

to increase soluble lead by $1000 \mathrm{ppb}$ due to reasonably anticipated complexation reactions.

Lead in drinking water can be present as truly dissolved soluble species (e.g., $\mathrm{Pb}^{2+}, \mathrm{Pb}\left(\mathrm{CO}_{3}{ }^{-2}\right)_{2}$ or as colloids/ particulates that can include detached solder, brass, or lead scale $(10,23)$. In the pipes with high nitrification (no inhibitor), average soluble lead was gradually increased from 60,220 , to $850 \mathrm{ppb}$ as alkalinity levels were dropped from 100, 30, to $15 \mathrm{mg} / \mathrm{L}$, respectively (Figure 3 ). When alkalinity was dropped from 15 to $0 \mathrm{mg} / \mathrm{L}$ as $\mathrm{CaCO}_{3}$, soluble lead decreased to 160 $\mathrm{ppb}$, most likely because the final $\mathrm{pH}$ was much higher (Figure 1). Throughout these tests particulate lead stayed relatively 


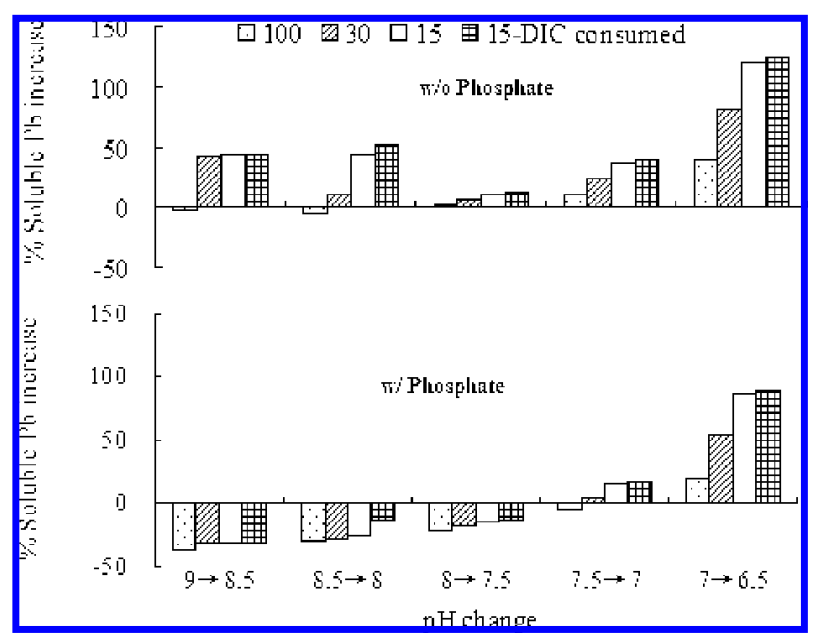

FIGURE 4. Predicted $\%$ soluble lead increase due to $\mathrm{pH}$ decrease (assuming $2000 \mathrm{ppb}$ lead). Lower graph assumes solubility control by $\mathrm{Pb}_{3}(\mathrm{PO} 4)_{2}$ solids.

constant at around $200 \mathrm{ppb}$ (Figure 3). In the pipes with low nitrification (monochloramine/chlorite), neither soluble nor particulate lead was significantly changed (Figure 3). Thus, nitrification could markedly increase the soluble lead release but had no strong detrimental impact on the particulate lead release (Figure 3).

Solubility models were used as described elsewhere to better understand the interplay between $\mathrm{pH}$ drops, alkalinity, buffering, dissolved inorganic carbon (DIC), and lead solubility $(24,25)$. Percent changes in soluble lead in response to various 0.5 unit $\mathrm{pH}$ drops were calculated as a function of initial alkalinity and $\mathrm{pH}$ change (Figure 4). In the absence of lead phosphate solids, soluble lead is predicted to markedly increase when $\mathrm{pH}$ drops, and the percentage increase is very significant at the lower alkalinities (Figure 4). For example, predicted soluble lead levels increase by $120 \%$ (from 470 to $1035 \mathrm{ppb}$ ) when $\mathrm{pH}$ drops from 7 to 6.5 at $15 \mathrm{mg} / \mathrm{L}$ alkalinity. However, if the water has $100 \mathrm{mg} / \mathrm{L}$ alkalinity, a pH drop from 7 to 6.5 only increases predicted soluble lead by $40 \%$ (from 320 to $447 \mathrm{ppb}$ ) (Figure 4).

The solubility model trends and observed impacts of lower $\mathrm{pH}$ on lead release are also consistent with utility experience and other recent data (4). That is, the effects of $\mathrm{pH}$ on lead contamination and lead solubility are relatively weak at the higher alkalinities. For example, the 90\%ile lead levels reported by utilities are not a strong function of $\mathrm{pH}$ if alkalinity is $>30 \mathrm{mg} / \mathrm{L}$, but lower $\mathrm{pH}$ markedly increases $90 \%$ ile lead if alkalinity is $<30 \mathrm{mg} / \mathrm{L}(26)$.

In situations where a $\mathrm{Pb}_{3}\left(\mathrm{PO}_{4}\right)_{2}$ solid controls solubility, a pH drop from 8 to 7.5 , or even from 8.0 to 7.0 , has relatively little effect on soluble lead, especially at higher alkalinities (Figure 4). In fact, the lower $\mathrm{pH}$ can even decrease lead solubility in some cases. In systems where a $\mathrm{Pb}_{3}\left(\mathrm{PO}_{4}\right)_{2}$ solid controls solubility, the final $\mathrm{pH}$ must drop down to about $\mathrm{pH}$ 6.5 before lead solubility is markedly increased (Figure 4); even then, changes in absolute lead concentrations are low relative to the $15 \mathrm{ppb}$ action level. For example, at $15 \mathrm{mg} / \mathrm{L}$ alkalinity, soluble lead levels are predicted to be 9 and 16 $\mathrm{ppb}$ at pH 8 and 6.5, respectively. The key conclusion is that $\mathrm{pH}$ drops from nitrification might not increase lead solubility at utilities dosing high doses of orthophosphate corrosion inhibitors.

The models were also used to examine the possible role of decreased DIC in the water due to autotrophic growth of nitrifying bacteria. Consideration of this factor predicted only slight impacts on soluble lead (Figure 4), supporting the idea that the primary effect of nitrification is exerted through its impact on $\mathrm{pH}$.

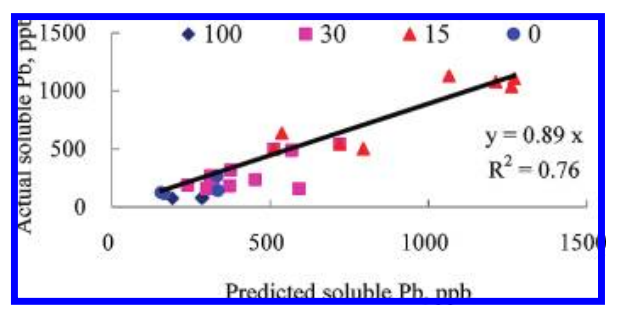

FIGURE 5. Actual soluble lead vs predicted soluble lead in lead pipes at the control condition with $1 \mathrm{mg} / \mathrm{L}-\mathrm{P}$. $\mathrm{Pb}_{3}\left(\mathrm{PO}_{4}\right)_{2}$ or similar solids were not predicted to form due to high removal of phosphate during stagnation.

Direct Comparison of Model Results to Experimental Data. For the experiments conducted herein, the initial phosphate in the water was virtually all removed during stagnation in the lead pipe. Even when the initial water contained $1000 \mathrm{ppb}$ phosphate, only $10 \mathrm{ppb}$ phosphate was present in the water after stagnation (i.e., $>99 \%$ had been removed by reactions with the lead pipe wall). To explain this loss, even assuming a very low corrosion rate of $0.1 \mathrm{uA} /$ $\mathrm{cm}^{2}$, the $\mathrm{Pb}^{2+}$ formed per unit volume of water in the pipe exceeds the phosphate that is present by more than an order of magnitude. Hence, the extreme loss of phosphate from the water by processes such as sorption to newly forming lead hydroxyl-carbonate scale is not unexpected. This may explain why the data in Figure 2 behave more like that expected for a system without phosphate inhibitor because the added phosphate was effectively removed and $\mathrm{Pb}_{3}\left(\mathrm{PO}_{4}\right)_{2}$ was undersaturated in these tests. In a practical situation with more frequent water changes and flow, it is highly likely that $\mathrm{Pb}_{3}\left(\mathrm{PO}_{4}\right)_{2}$ solid would have formed and controlled soluble lead. Thus, results in this set of experiments are more representative of expectations at utilities that do not dose a high amount of orthophosphate to the water.

The solubility model predictions (based on measured final $\mathrm{pH}$, final total lead, total phosphate, and final alkalinity) are in good agreement with the actual data on soluble lead for situations with high nitrification $\left(R^{2}=0.76\right)$ (Figure 5). The conclusion is that the complex response of soluble lead to initial alkalinity (Figure 2) is completely consistent with solubility model predictions that consider lead-carbonate solid formation, lead carbonate complexation, and other factors $(24-27)$. This good correlation also is consistent with earlier calculations, which suggested that complexation by SMP is not a major contributor to the increased soluble lead after nitrification.

It is worth reiterating that higher alkalinity has an important dual benefit in preventing problems with increased soluble lead due to nitrification. First, as a buffer, the extent of the $\mathrm{pH}$ drop due to a given amount of ammonia conversion is reduced. This is obvious based on the average $\mathrm{pH}(-\log$ of average $\left[\mathrm{H}^{+}\right]$) of $7.7,6.92$, and 6.19 at 100,30 , and $15 \mathrm{mg} / \mathrm{L}$ alkalinity, respectively (Figure 1). Second, a given $\mathrm{pH}$ drop of 0.5 units also has a much lesser impact on soluble lead at higher alkalinity (Figure 4).

Nitrification Effects at Lower Phosphate Levels. In nearly all tests with lower levels of phosphate or with nitrification inhibitors relatively little nitrification occurred. As a result, the final $\mathrm{pH}$ was higher and soluble lead levels were lower when compared to the control condition dosed with $1 \mathrm{mg} /$ L-P. At these lower levels of phosphate the solubility model did not predict trends quite as well as for cases where extensive nitrification occurred (e.g., Supporting Information, Figure S-2). This is probably because the soluble lead was a relatively small fraction $(10-42 \%)$ of the total lead present, and soluble lead data therefore has higher error due to significant interference from colloids less than $0.45 \mu \mathrm{m}$ in size (23) when the fraction of soluble lead is low relative to total lead. The observed reduction in nitrification at lower 
TABLE 1. Water Utility Studies Results ${ }^{a}$

\begin{tabular}{|c|c|c|c|c|c|c|c|c|c|c|}
\hline & site & $\begin{array}{c}\text { service } \\
\text { pipe material }\end{array}$ & $\begin{array}{c}\text { ammonia decrease, } \\
\mathrm{mg} / \mathrm{L}\end{array}$ & $\begin{array}{l}\mathrm{POE} \\
\mathrm{pH}\end{array}$ & $\begin{array}{c}\text { alkalinity, } \\
\mathrm{mg} / \mathrm{L}\end{array}$ & $\begin{array}{l}\text { predicted } \\
\text { pH drop }\end{array}$ & $\begin{array}{l}\text { actual } \\
\mathrm{pH} \text { drop }\end{array}$ & $\begin{array}{l}\text { total } \\
\mathrm{Pb}, \mathrm{ppb}\end{array}$ & $\begin{array}{l}\text { total } \\
\text { Cu, ppb }\end{array}$ & $\begin{array}{c}\text { total } \\
\mathrm{Zn}, \mathrm{ppb}\end{array}$ \\
\hline \multirow[t]{3}{*}{ St. Paul, MN } & 1 & lead & 0.4 & 9 & 42 & 0.5 & 0.12 & 261 & 771 & 8 \\
\hline & 2 & & 0.8 & & 38 & 1 & 0.72 & 58 & 15 & 21 \\
\hline & 3 & & 0.18 & & 39 & 0.2 & -0.18 & 8 & 31 & 269 \\
\hline \multirow[t]{3}{*}{ anonymous } & 1 & & 0.41 & 8.3 & 44 & 0.62 & 0.6 & 7 & 550 & 486 \\
\hline & 2 & & 0.34 & & 49 & 0.54 & 0.3 & 2 & 215 & 52 \\
\hline & 3 & & 0.38 & & 51 & 0.54 & 0 & 5 & 180 & 135 \\
\hline \multirow[t]{3}{*}{ Portland, OR } & 1 & copper & 0.23 & 7.8 & 10 & 0.57 & 0.5 & 7 & 312 & 13 \\
\hline & 2 & & 0.18 & & 13 & 0.57 & 0.3 & 21 & 944 & 34 \\
\hline & 3 & & 0.32 & & 11 & 0.82 & -1.1 & 4 & 177 & 11 \\
\hline \multirow{2}{*}{ Bangor, ME } & 1 & copper & 0.6 & 9.73 & 22 & 0.35 & 0.71 & 4.8 & 331 & 70 \\
\hline & 2 & & 0.62 & & 22 & 0.35 & 0.58 & 49 & 228 & 6 \\
\hline \multirow[t]{3}{*}{ Hampden, ME } & 1 & cast iron & 0.35 & 9.6 & 26 & 0.16 & 1.8 & 1 & 81 & 12 \\
\hline & 2 & plastic & 0.44 & & 25 & 0.2 & 1.99 & 658 & 444 & 168 \\
\hline & 3 & copper & 0.08 & & 25 & 0.03 & 0.15 & 12 & 187 & 24 \\
\hline
\end{tabular}

${ }^{a}$ Note: Data reported represents the 1st draw sample after overnight stagnation. Calculations are made by comparing water quality to those collected at the POE.

TABLE 2. Montana Bench Test Results ${ }^{a}$

\begin{tabular}{|c|c|c|c|c|c|}
\hline $\begin{array}{c}\text { pipe } \\
\text { material }\end{array}$ & $\begin{array}{c}\text { ammonia } \\
\text { loss, \% }\end{array}$ & final $\mathrm{pH}$ & $\begin{array}{c}\text { total } \\
\mathrm{Pb}, \mathrm{ppb}\end{array}$ & $\begin{array}{c}\text { total } \\
\mathrm{Zn}, \mathrm{ppb}\end{array}$ & $\begin{array}{c}\text { total } \\
\text { Cu, ppb }\end{array}$ \\
\hline $\begin{array}{l}\text { PVC } \\
\text { copper }\end{array}$ & $\begin{array}{r}71 \pm 3 \\
6 \pm 5\end{array}$ & $\begin{array}{l}6.77 \pm 0.06 \\
9.77 \pm 0.13\end{array}$ & $\begin{array}{l}67 \pm 3 \\
46 \pm 4\end{array}$ & $\begin{array}{l}763 \pm 33 \\
421 \pm 30\end{array}$ & $\begin{array}{c}75 \pm 5 \\
1500 \pm 128\end{array}$ \\
\hline
\end{tabular}

levels of phosphate is attributed to a limiting nutrient effect and will be the subject of future research.

Case Studies. Water Utility Studies. Samples collected from homes at five utilities using chloramines indicated extensive nitrification during stagnation, as confirmed via a measured decrease of ammonia (Table 1) and increase of nitrite/nitrate species. Similar to our earlier field studies (19), significant $\mathrm{pH}$ drops $(0.34-2 \mathrm{pH}$ unit) were also documented (Table 1). When the actual $\mathrm{pH}$ drop is compared to the $\mathrm{pH}$ drop predicted based solely on ammonia consumption via nitrification, the actual $\mathrm{pH}$ drop was sometimes higher or sometimes lower than the predicted $\mathrm{pH}$ drop (Table 1). This was not surprising considering the complexity of other microbial and chemical reactions that can occur in pipes during stagnation (Figure 2). However, there are also cases where the predicted $\mathrm{pH}$ drop was very close to the actual $\mathrm{pH}$ drop, for example, site 1 in the anonymous and Portland utility.

For samples collected at a given utility the magnitude of the $\mathrm{pH}$ drop among different sampling sites was generally consistent with the ranking of ammonia consumption (Table 1). An exception was site 3 in Portland, OR, where the ammonia consumption was high but $\mathrm{pH}$ was observed to increase rather than decrease. This was possibly due to the presence of concrete-lined pipes in the system, which can leach lime to water, as confirmed by higher calcium levels in water samples from this site compared to the other two (5 versus $2 \mathrm{mg} / \mathrm{L}$ ).

For all utilities investigated, the sampling sites with the smallest ammonia consumption and pH drop usually had the least lead, copper, or zinc contamination (site 3 within each utility). Overall, the level of lead, copper, and zinc contamination was somewhat controlled by the magnitude of the $\mathrm{pH}$ drop caused by nitrification. Because the plumbing materials present in each home will vary markedly in terms of lead content, strong correlations between $\mathrm{pH}$ drop and lead leaching cannot be expected.

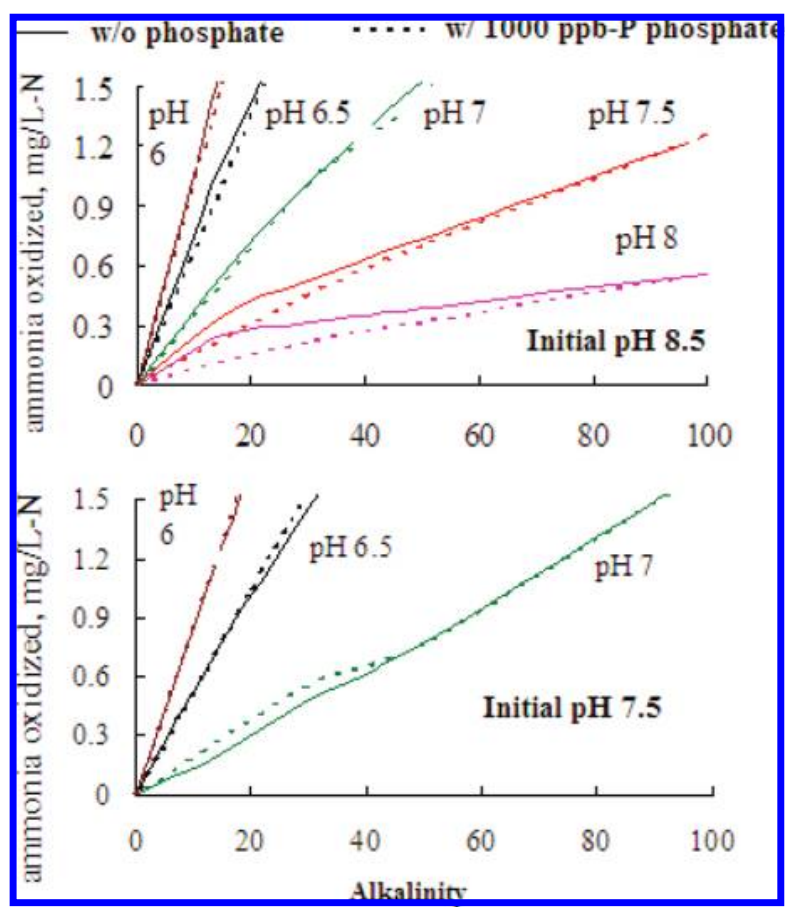

FIGURE 6. Resulting pH drop based on ammonia oxidized at different initial alkalinities. Lines indicate final $\mathrm{pH}$.

Montana Bench Test. Consistent with results based on prior research documenting the role of copper in controlling nitrification (4), complete nitrification occurred in PVC pipes after 2 months but never occurred in copper pipes even after 9 months (Table 2). In PVC pipes nitrification decreased the final $\mathrm{pH}$ to 6.77, while in copper pipes final $\mathrm{pH}$ was increased to 9.96 , possibly due to copper corrosion (19) (Table 2). Not surprisingly, the average lead and zinc released from the leaded brass exposed to water at a lower final $\mathrm{pH}$ in the PVC pipes were $45 \%$ and $81 \%$ higher, respectively, than observed in copper pipes (Table 2).

This type of effect also may have been observed at one of the utilities sampled (Table 1, Hampden, MN). Higher copper, lead, and zinc were observed in homes with plastic rather than copper service line plumbing. Overall, these data offer clear proof that in situations where nitrification is occurring and leaded brass faucets are present the first draw lead might be higher in homes plumbed with PVC/plastic pipe versus homes plumbed with copper pipe (4). 
Implications for Drinking Water Systems. Nitrification can sometimes increase soluble lead contamination of potable water by reducing $\mathrm{pH}$. In considering the possible effects of nitrification on lead solubility for a given circumstance, the "worst case" $\mathrm{pH}$ drop from nitrification (assuming $100 \%$ conversion of total ammonia) for a utility (Figure 6 and Figure S-3, Supporting Information) can be calculated. For example, at a utility with an initial $\mathrm{pH}$ of 8.5 and $40 \mathrm{mg} / \mathrm{L}$ initial alkalinity and $1 \mathrm{mg} / \mathrm{L} \mathrm{NH}_{3}-\mathrm{N}, \mathrm{pH}$ is expected to drop up to $1.5 \mathrm{pH}$ units due to nitrification (Figure 6). The lead solubility models (i.e., Figure 4 ) can then be used to predict that the 1.5 unit drop in $\mathrm{pH}$ from 8.5 to 7 could increase soluble lead by $50 \%$.

This analysis indicates that the initial $\mathrm{pH}$ also plays an important dual role. First, systems with $\mathrm{pH}$ between 7.5 and 8 are more likely to have active nitrification (28). Second, a given amount of nitrification activity would induce a much larger $\mathrm{pH}$ drop in systems with an initial $\mathrm{pH}$ of $8-8.5$ since buffer intensity is at minimum at $\mathrm{pH}$ $=8.3$ in carbonate systems (29). For example, comparing site 1 at St Paul, MN, and the anonymous utility with similar initial alkalinities ( 42 and $44 \mathrm{mg} / \mathrm{L}$ ) and ammonia loss (0.4 and $0.41 \mathrm{mg} / \mathrm{L}$ ) the predicted $\mathrm{pH}$ drop due to nitrification is 0.5 unit in St Paul, MN (initial pH of 9), and 0.61 unit in the anonymous utility (initial pH of 8.3) (Table 1). The actual pH drop in St. Paul, MN, was even smaller: $0.12 \mathrm{pH}$ unit (Table 1).

The overall conclusion is that serious problems with lead leaching from nitrification are not expected at the alkalinities and initial pHs encountered at a majority of water utilities. Hence, use of Figures 6 and 4 can serve as an important screening tool to consider a utility's susceptibility to problems with higher soluble lead as a result of nitrification. Use of these figures does indicate that utilities like Ottawa, Canada (initial pH 8.5 and initial alkalinity $35 \mathrm{mg} / \mathrm{L}$ ) (7), are very susceptible to elevated soluble lead from nitrification. Similar approaches can be taken for evaluating copper leaching problems due to nitrification; however, contrary to lead release, copper solubility is most strongly affected by $\mathrm{pH}$ changes in higher alkalinity waters, like Willmar, MN (6).

\section{Acknowledgments}

This work was supported by American Water Works Association Research Foundation (AWWARF) and the United States Environmental Protection Agency (USEPA). Matching funds to that grant were also provided by the Copper Development Association (CDA), Bangor (ME), Hampden (ME), St Paul (MN) and Portland (OR) water utilities. The opinions, findings, conclusions, or recommendations are those of the authors and do not necessarily reflect the views of AWWARF, USEPA, the CDA, or the water utilities.

\section{Supporting Information Available}

Additional figures and tables regarding actual versus predicted $\mathrm{pH}$ drops and soluble lead, $p$ value for paired $t$ test on total and soluble lead, and detailed sampling procedures for field studies. This material is available free of charge via the Internet at http://pubs.acs.org.

\section{Literature Cited}

(1) Zhang, Y.; Love, N.; Edwards, M. Nitrification in drinking water systems. Crit. Rev. Environ. Sci. Technol. 2008, in press.

(2) Seidel, C. J.; Mcguire, M. J.; Summers, S.; Via, S. Have utilities switched to chloramines? I. Am. Water Works Assoc. 2005, 97 (10), 87-97.
(3) Wilczak, A.; Jacangelo, J. G.; Marcinko, J. P.; Odell, L. H.; Kirmeyer, G. J.; Wolfe, R. L. Occurrence of nitrification in chloraminated distribution systems. J. Am. Water Works Assoc. 1996, 88 (7), 74-85.

(4) Zhang, Y.; Griffin, A.; Edwards, M. Nitrification in premise plumbing: Role of phosphate, $\mathrm{pH}$ and pipe corrosion. Environ. Sci. Technol. 2008, 42 (12), 4280-4284.

(5) Powell, R. Implementation of chloramination by a Florida utility: The good, the bad, and the ugly. AWWA WQTC conferences, San Antonio, TX, 2004.

(6) Murphy, B.; O'Connor, J. T.; O'Connor, T. L. Willmar, Minnesota battles copper corrosion-part 2. Public Works 1997, 128 (12), $44-47$.

(7) Douglas, I.; Guthmann, J.; Muylwyk, Q.; Snoeyink, V. Corrosion control in the city of Ottawa-comparison of alternatives and case study for lead reduction in drinking water. Eleventh Canadian National Conference and Second Policy Forum on Drinking Water, 2004.

(8) Edwards, M.; Dudi, A. Role of chlorine and chloramine in corrosion of lead-bearing plumbing materials. $\underline{\text {. Am. Water }}$ Works Assoc. 2004, 96 (10), 69-81.

(9) Edwards, M.; Triantafyllidou, S. Chloride-to-sulfate mass ratio and lead leaching to water. J.Am. Water Works Assoc. 2007, 99 (7), 96-109.

(10) Triantafyllidou, S.; Parks, J.; Edwards, M. Lead particles in potable water. L. Am. Water Works Assoc. 2007, 99 (6), 107-117.

(11) Committee on Public Water Supply Distribution Systems: Assessing and Reducing: Risks, N. R. C. Drinking water distribution systems: Assessing and reducing risks; The National Academy Press: Washington, DC, 2006.

(12) Fleming, K. K.; Harrington, G. W.; Noguera, D. R. Nitrification potential curves: A new strategy for nitrification prevention. J. Am. Water Works Assoc. 2005, 97 (8), 90-99.

(13) McGuire, M. J.; Lieu, N. I.; Pearthree, M. S. Using chlorite ion to control nitrification. J.Am. Water Works Assoc. 1999, 91 (10), $52-61$.

(14) McGuire, M. J.; Pearthree, M. S.; Blute, N. K.; Arnold, K. F.; Hoogerwerf, T. Nitrification control by chlorite ion at pilot scale. J. Am. Water Works Assoc. 2006, 98 (1), 95-105.

(15) Clesceri, L. S.; Greenberg, A. E.; Eaton, A. D. Standard methods for the examination of water and wastewater, 20th ed.; American Public Health Association and American Water Works Association and Water Environment Federation: Washington, DC, 1998.

(16) Rahman, M. S. Nitrification in premise plumbing systems; Montana State University: Bozeman, MT, 2008.

(17) Grady, C. P. L.; Daigger, G. T.; Lim, H. C. Biological wastewater treatment, 2nd ed.; Marcel Dekker, Inc.: New York, 1999.

(18) AWWA. Water stats survey/database; Denver, CO, 1996.

(19) Zhang, Y.; Triantafyllidou, S.; Edwards, M. Effect of nitrification and GAC filtration on copper and lead leaching in home plumbing systems. ASCE J. Environ. Eng. 2008, 134 (7), 521530.

(20) Garret, J. H. The action of water on lead; H.K. Lewis: London, 1891.

(21) Odell, L. H.; Kirmeyer, G. J.; Wilczak, A.; Jacangelo, J. G.; Marcinko, J. P.; Wolfe, R. L. Controlling nitrification in chloraminated systems. L. Am. Water Works Assoc. 1996, 88 (7), 86-98.

(22) Rittmann, B. E.; Regan, J. M.; Stahl, D. A. Nitrification as a source of soluble organic substrate in biological treatment. Water Sci. Technol. 1994, 30 (6), 1-8.

(23) McNeill, L. S.; Edwards, M. Importance of $\mathrm{Pb}$ and $\mathrm{Cu}$ particulate species for corrosion control. L. Environ. Eng.-ASCE 2004, 130 (2), 136-144.

(24) Internal corrosion of water distribution systems, 2nd ed.; American Water Works Association Research Foundation and DVGW-Technologiezentrum Wasser: Denver, CO, 1996.

(25) Schock, M. R. Understanding corrosion control strategies for lead. J. Am. Water Works Assoc. 1989, (7), 81.

(26) Dodrill, D.; Edwards, M. Corrosion control on the basis of utility experience. J. Am. Water Works Assoc. 1995, 87 (7), 74-85.

(27) Edwards, M.; Jacobs, S.; Dodrill, D. Desktop guidance for mitigating $\mathrm{pb}$ and cu corrosion by-products. J.Am. Water Works Assoc. 1999, 91 (5), 66-77.

(28) Wolfe, R. L.; Lieu, N. I. Nitrifying bacteria in drinking water. Encycl. Environ. Microbiol. 2001, 2167-2175.

(29) Snoeyink, V. L.; Jenkins, D. Water chemistry; John Wiley \& Sons: New York, 1980.

\section{ES802482S}

